\title{
Paula Fredriksen When Christians Were Jews: The First Generation
}

(New Haven and London: Yale University Press, 2018), Hardcover, 261 pp.

\author{
PHILIP A. CUNNINGHAM \\ pcunning@sju.edu \\ Saint Joseph's University, Philadelphia, PA 19131
}

Paula Fredriksen is the author of several earlier, highly-regarded volumes, including From Jesus to Christ: The Origins of the New Testament Images of Christ (2nd ed., 2000); Augustine and the Jews: A Christian Defense of Jews and Judaism (2008); and most recently, Paul: The Pagans' Apostle (2017). Her latest book is a study of the first four decades of what would become Christianity, focusing on the years between the execution of Jesus around 30 C.E. and the destruction of the Second Temple in 70 C.E.

After a few opening pages in which she offers a marvelously concise summary of the historical backdrop of the time of Jesus, in the first chapter she considers his travels as a charismatic preacher of the imminent Kingdom of God. She argues that the Johannine itinerary in which Jesus is a regular presence in Jerusalem is to be preferred over the synoptic accounts that have him in Jerusalem only on the Passover when he died (except for Luke 2). She likewise claims that the activities of the first believers that the crucified one had been raised also occurred in Jerusalem.

Her proposal that Jesus was a familiar figure in Jerusalem raises the question, examined in chapter 2, as to what made the Passover on which he was crucified different from all his earlier festival celebrations in the city. As Fredriksen puts it, "we must account both for Pilate's and Caiaphas's initial inaction [to Jesus for several years when he was announcing that God's Kingdom was at hand], and for their eventual response: the arrest and execution of Jesus and of Jesus alone [and none of his disciples]" (p. 66; emphasis in original). She wonders if "Jesus may have shifted the time frame of his prophecy, from soon to now.... Was that Passover in Jerusalem to be the last before the Kingdom came?" (pp. 68-69; emphasis in original). Although in this reconstruction of admittedly scanty evidence, the authorities did not consider Jesus to be a violent threat himself (hence his follow- 
ers were not also rounded up), it was the unpredictability of the throngs crowded into Jerusalem for the Passover that prompted them to execute the very popular Jesus: "The restive pilgrim crowds in the city — enthusiastically celebrating Jesus, proclaiming him the messiah, stirred up especially on this Passover by Jesus' naming it as the date of the Kingdom's advent - would have already sealed his fate" (pp. 72-73; emphasis in original). Perhaps an entourage of several hundred people accompanied Jesus to Jerusalem and hailed him there in messianic terms (p. 90), a demonstration that would surely alarm the city's leaders.

In chapter 3 she addresses how the crucified Jesus became "the Christ." His unexpected death, Fredriksen states, totally perplexed his followers: "If Jesus were dead, how could his prophecy [about the Kingdom's arrival] be true? If Jesus' prophecy were true, how could he be dead?" (p. 75). Jesus' traumatized admirers were able to move beyond this conundrum after becoming convinced that he had been raised: "Resurrection both resolved this dissonance, and reinforced the prophecy. If Jesus were raised, then the Kingdom must truly be at hand" (p. 75). Turning to the various New Testament "appearance narratives," Fredriksen describes a limited period of time during which "his followers continue to experience the risen Jesus" (p. 79). Although the resurrection of a single individual was not among the apocalyptic expectations current in late Second Temple Judaism, for this first generation of Jesus' followers, says Fredriksen, their experience "was for them meaningful as the first of a cascade of anticipated Endtime events" (pp. 86-87). His followers initially stayed in Jerusalem, the site of God's holy mountain where all the nations were expected to gather when the Kingdom dawned: "For Jesus' followers in these heady weeks of serial resurrection appearances, time now balanced at the very edge of the End. To be any place other than Jerusalem, simply made no sense" (pp. 92-93). Then the appearances ceased and the Endtime had still not come. Having already begun to reread Israel's scriptures in unprecedented ways, the first generation concluded that they were not meant to sit and wait: "They themselves would continue Jesus' mission to prepare Israel - because clearly, in light of the Kingdom's delay, all Israel had yet to be reached" (p. 101; emphasis in original). Thus, they turned to the Diaspora, where more Jews lived than in the biblical homeland.

In her reading of a key Pauline verse, Fredriksen in chapter 4 considers the RSV's translation of Romans 1:4 to be misleading. It is not his resurrection that has shown that Jesus is the son of God, rather Jesus will be revealed as the messiah when all the dead are raised upon his return as a triumphant Davidic figure. The apostles of Jesus, announcing all this in the Jewish Diaspora, were startled to discover that the pagan gentile "god-fearers" found in some Hellenistic synagogues were eager to learn more. Jesus had left no instructions for such an eventuality. So the apostles improvised. Reinterpreting "the expectation that, in the End, the nations too would renounce their false gods and worship the one true god alongside of Israel ... [they] welcomed these pagans into their new assemblies" (p. 142). However, they insisted that they disassociate themselves completely from their former gods and rituals: "By committing to Israel's god alone, they were no longer pagans: ... they were eschatological gentiles. What 
greater confirmation that the times were fulfilled, that the Kingdom of God was truly at hand?" (p. 142; emphasis in original).

In chapter 5, Fredriksen explores the social impact of these developments. Whereas Jews who joined the Jesus movement "did not 'convert' so much as make a lateral move within Judaism," pagans who were baptized into the movement "could no longer worship their native gods, the gods of their families and of their cities. They had to commit exclusively, these apostles taught, to the worship of the god of Israel" (p. 150). The potential for the significant destabilization of urban Greco-Roman religious pluralism was great: "Allegiance to the Jesusassembly for the pagan ... required a much more radical form of Judaizing than the synagogue had ever requested ... What if the gods, insulted and angry, struck back? And what if pagan neighbors, anxious and angry [after some disaster such as an earthquake], struck at the synagogue, the obvious source of this disruptive new movement?" (p. 151).

Fredriksen then refocuses on Jerusalem. Jesus' followers had a "ringside seat, in 39-40 C.E., for a totally unanticipated confrontation, a battle of the gods" (p. 162) when Caligula ordered a statue of himself to be placed in the Jerusalem temple. For the Jesus community, "all the signs converged ... Now was the time of Jesus' return ... with great power and glory, gathering his elect, ruling over the nations, raising the dead, establishing the Kingdom" (p. 167). Caligula's assassination avoided a certain Jewish revolt against Rome, but a few decades later, as the first generation of Jesus' believers was dying off, that war finally erupted, in 66 C.E. Apocalyptic fervor again flared up and in the conflagration of Jerusalem the original Jesus-assembly disappeared.

In her concluding epilogue, Fredriksen makes a number of important points, characteristically coining several masterful turns-of-phrase. She observes that she has "avoided using the terms 'Christian' and 'church," which too easily invoke images of a separate religion that grew hostile to Judaism: "But in its founding generation - which was committed to the belief that it was history's final generation-members of this movement were traditionally observant Jews. Paul included. (And ... so was Jesus.)" (p. 185). To illustrate the diversity of late Second Temple Judaism, she suggests that one "imagine the Torah as widely dispersed sheet music: the notes were the notes, but Jews played a lot of improv. The gospels, too, are a genre of Jewish scriptural improvisation" (p. 185).

To understand the "divinization" of Jesus by Paul and others, she stresses that in the ancient world "divinity" and "humanity" were not understood in modern binary categories: "For Jews as for the pagan contemporaries, divinity was constructed and construed along a gradient that spanned heaven and earth. The very architecture of the universe - earth at the center, then the moon, then the five planets and the sun, then the realm of the fixed stars-articulated these grades. Special humans were divine. ... Back in the mid-first century, when Christians were Jews, Jesus was high on the cosmic gradient, but he was nonetheless human" (pp. 186-187). 
In an upturning of much earlier scholarship, Fredriksen convincingly argues that Paul, Peter, and James were all agreed: "as long as god-fearing pagans, once immersed 'into Christ,' took the step to radically Judaize their cultic life, worshiping only Israel's god and shunning their own gods and their former idols, they were 'in"” (p. 188). They were "eschatological gentiles," non-Jews devoted exclusively to Israel's deity at the End of Days.

Finally, in her closing paragraphs, Fredriksen wryly notes that she disputes her own book's title: “'Christians' is an anachronistic term for this first generation, and therefore a distorting one. 'Christianity' conjures images of bishops and doctrines, of creeds, of ordered theology ... not [a community that is] unstable, vibrant, energetic, conflicted, even impatient, glowing with charismata on time's edge. If we use 'Christian' of this first generation, we pull them out of their own context, domesticating them for ours" (p. 191).

This is probably the biggest lesson that the book imparts. While one can argue with some of the details of her historical reconstruction (e.g., did Jesus really say that a certain Passover was the specific time of the Kingdom's coming? Can one just accept Acts' contention that resurrection "appearances" ceased without more analysis of the relevant narratives?), the developmental trajectory that Fredriksen describes is compelling and filled with rich insights and suggestions. When Christians Were Jews deserves a wide readership and will reward careful study. 